\title{
Pancreatic cancer or autoimmune pancreatitis: Endosonography as a diagnostic reviser
}

\author{
Viktória Terzin ${ }^{1}$, Mariann Dobra ${ }^{2}$, Csaba Góg ${ }^{2}$, Edit Zábrák ${ }^{3}$, Éva Makula ${ }^{4}$, László Tiszlavicz ${ }^{5}$, \\ Tamás Kiss ${ }^{1}$, Tamás Molnár ${ }^{1}$, Ferenc Nagy ${ }^{1}$, László Czakó ${ }^{1}$, Tibor Wittmann ${ }^{1}$, Zoltán Szepes ${ }^{1}$ \\ 1. First Department of Internal Medicine, University of Szeged, Szeged, Hungary. 2. Internal Medicine Unit, Dr. \\ Diósszilágyi Sámuel Hospital, Makó, Hungary. 3. Radiology Unit, Dr. Diósszilágyi Sámuel Hospital, Makó, Hungary. 4. \\ Department of Radiology, University of Szeged, Szeged, Hungary. 5. Department of Pathology, University of Szeged, \\ Szeged, Hungary.
}

Correspondence: Zoltán Szepes. Address: First Department of Internal Medicine, University of Szeged, 6720 Szeged, Korányi fasor 8-10, Hungary. Email: szepes.zoltan@med.u-szeged.hu.

Received: February 6, 2014

DOI : $10.5430 /$ crim.v1n2p126
Accepted: May 6, 2014

Online Published: May 14, 2014

URL: http://dx.doi.org/10.5430/crim.v1n2p126

\section{Abstract}

Conventional radiologic imaging (abdominal ultrasound, computer tomography) used in the differential diagnosis of post-hepatic jaundice can frequently provide inaccurate diagnosis. Inflammatory lesions may mimic neoplastic processes and malignancy may be accompanied by perifocal inflammation resulting in histological misdiagnosis. Furthermore, chronic and autoimmune pancreatitis are associated with an increased risk for pancreatic cancer. Radial endosonography has become a markedly important method in the imaging of the pancreas. It has a crucial role in the diagnosis and staging of pancreatic cancer. The authors present three cases where the diagnosis of pancreatic cancer determined by conventional imaging techniques (abdominal ultrasound, computer tomography, endoscopic retrograde cholangiopancreatography) was excluded or confirmed by the radial endosonography. The authors conclude that radial endosonography is an essential complementary method among imaging techniques of the pancreas and in tumor staging. Application of that may prevent unnecessary surgeries, which is obviously useful for patients and cost effective for health care providers.

\section{Keywords}

Jaundice, Radial endosonography core biopsy, Pancreatic cancer, Autoimmune pancreatitis, IgG4 positivity, Corticosteroid therapy

\section{I ntroduction}

According to their sensitivity the conventional radiological examinations, i.e. abdominal ultrasound (US) and computed tomography (CT), are rarely able to make a proper differentiation in the etiology of posthepatic jaundice. Inflammatory lesions in the pancreas may mimic neoplastic processes and malignancy may be accompanied by perifocal inflammation resulting in histological misdiagnosis. Furthermore, chronic and autoimmune pancreatitis (AIP) are associated with an increased risk of pancreatic cancer, that means an increase to approximately $4 \%$ after a 20 -year long period of the inflammation ${ }^{[1]}$. 
The radial endoscopic ultrasound (EUS) is a more precise diagnostic tool in pancreatic disorders, causes a break-through in visualizing the abnormalities of the organ. According to different reviews EUS plays an important role in differentiating the mass-forming benign and malignant lesions (it has the highest sensitivity and specificity among the radiological methods) in staging and in making decisions about operability ${ }^{[2,3]}$. It may help in distinguishing real tumors and tumor-mimicking inflammatory disorders (e.g. chronic pancreatitis - AIP) ${ }^{[4-9]}$. Furthermore it is a minimal invasive technique which may avoid the patient from the more invasive core-biopsy. According to the recent guidelines in case of a resectable solitary tumor there is no need for previous histological diagnosis ${ }^{[10]}$.

We would like to present three cases which at first may seem familiar, however the EUS was the imaging tool that led towards another way of diagnosis or confirmed the diagnosis, moreover in the third case it opposed the results of ultrasound-guided core-biopsy.

\section{Case presentation}

\subsection{First case}

A 74-year old woman was admitted to our Emergency Unit due to right hypochondrial crampy pain and jaundice. Blood samples taken on the first day revealed elevated transaminase and cholestatic enzyme levels beside normal amylase level (see Table 1). Abdominal US showed gallbladder stones, gallbladder wall thickening and a hypoechoic solid mass, $33 \mathrm{~mm}$ $\times 37 \mathrm{~mm}$ in size, in the head of the pancreas (see Figure 1). Abdominal CT revealed slightly widened head with surrounding fatty infiltration; the head partly compressed the descending part of the duodenum and a low-density mass, 23 $\mathrm{mm} \times 25 \mathrm{~mm} \times 30 \mathrm{~mm}$ in size, in the uncinate process. All of the imaging findings supported a tumor in the head of the pancreas (see Figure 2). Endoscopic retrograde cholangiography (ERC) was performed to ensure the bile flow, a slight external compression on the intrapancreatic part of the common bile duct was seen during the procedure, however there was no need for stenting (see Figure 3). To identify more precisely the lesion radial EUS was carried out which showed abdominal lymphadenomegaly with multiple solid nodules in the pancreas (see Figure 4) suggesting a diffuse involvement of the pancreas, moreover lymphoma was suspected.US-guided core-biopsy was made from the lesion in the head of the pancreas for differential diagnosis, the histological examination revealed fibrosis, atrophy of the acinar structures in the tissue sample, while the ducts were in relatively large number and lymphoplasmacytic infiltration was seen in the pancreatic tissue. Immunhistochemically a high number of immunoglobulin G4- (IgG4-) positive plasma cells were seen both in the pancreas and in the peripancreatic tissue (see Figure 5). According to these findings IgG4-associated AIP was diagnosed. The serum IgG4-level was extremely elevated which confirmed the diagnosis.

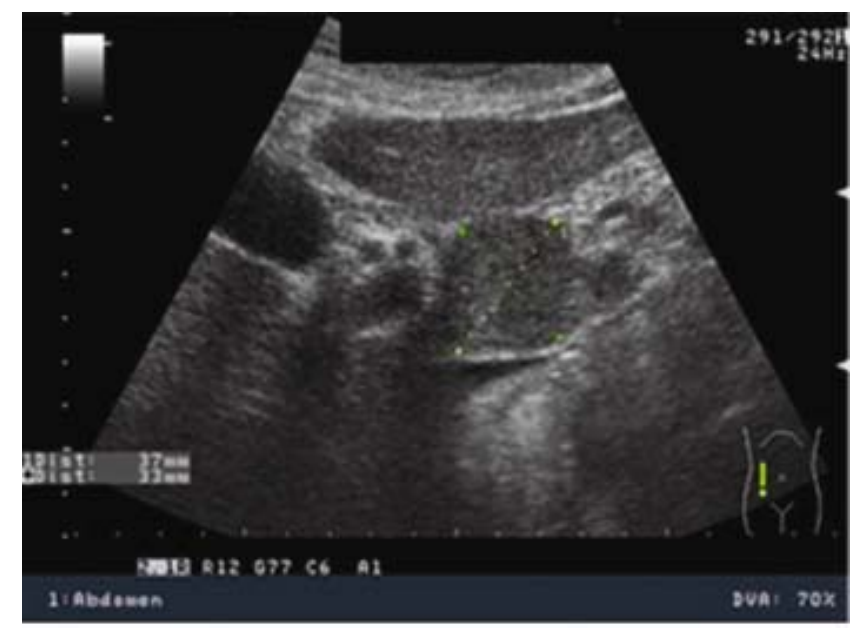

Figure 1. Abdominal US shows a hypoechoic solid mass, $33 \mathrm{~mm} \times 37 \mathrm{~mm}$ in size, in the head of the pancreas. 

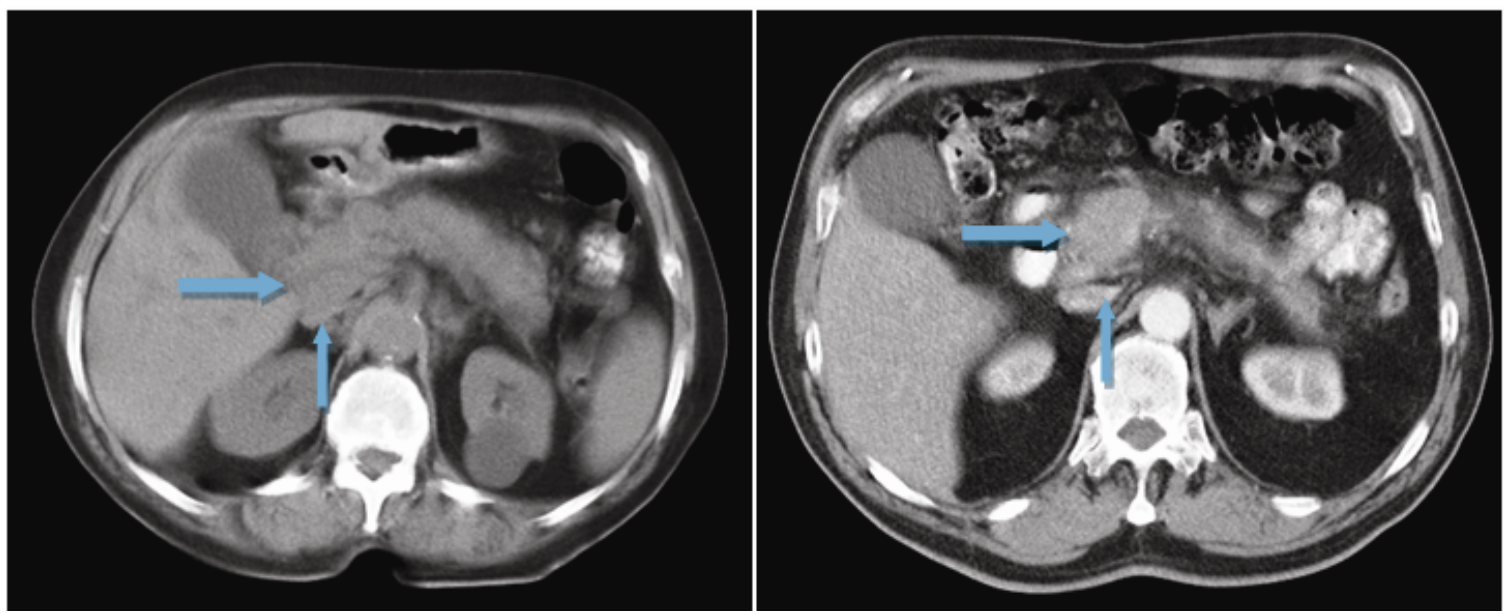

Figure 2. Widening of the head of the pancreas with surrounding fatty infiltration can be seen on abdominal CT (first case). On the right: mass in the pancreas (second case).
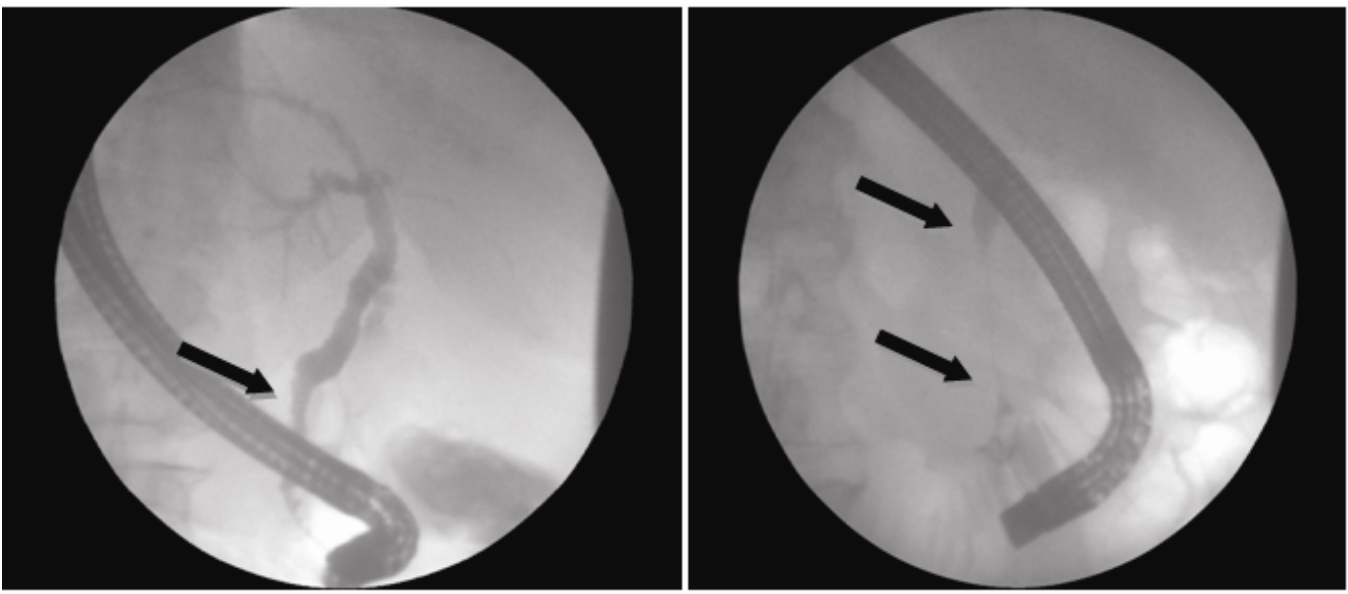

Figure 3. ERC examinations: on the left: a slight external compression on the intrapancreatic part of the common bile duct was seen, however there was no need for stenting (first case). On the right: bile duct stenosis before stenting (second case).
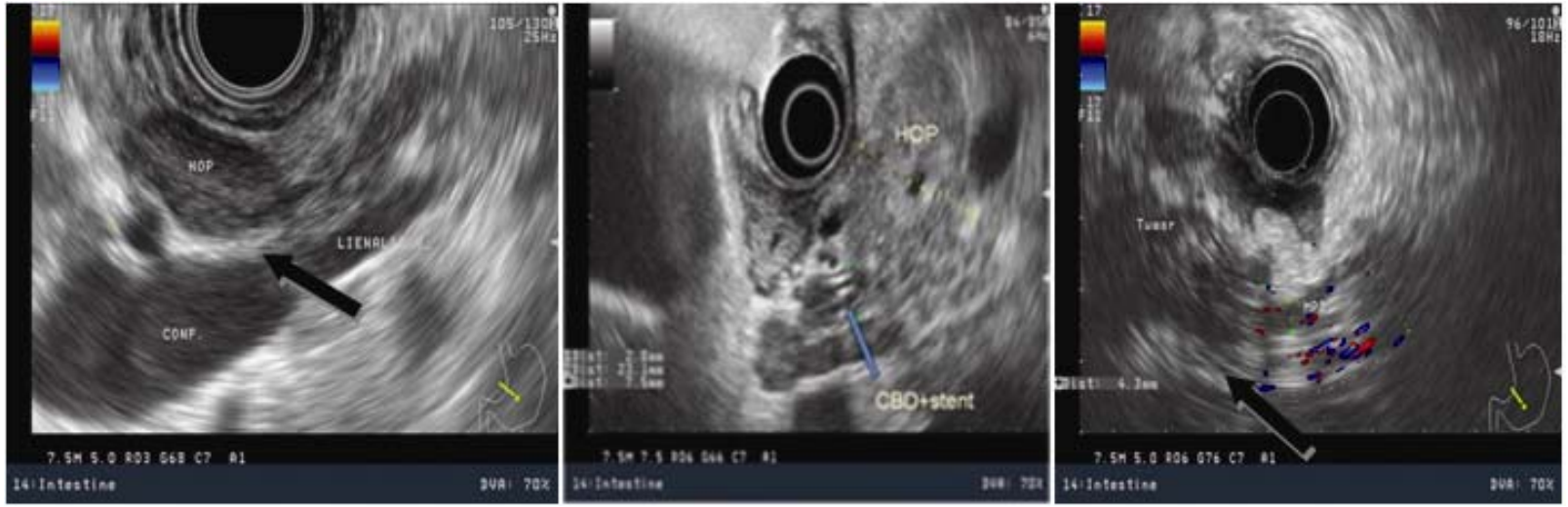

Figure 4. Endoscopic ultrasonography: on the left: abdominal lymphadenomegaly with multiple solid nodules in the pancreas (first case). In the middle: diffuse inhomogenous head, plastic stent in the common bile duct (second case). On the right: pancreatic cancer with vascular invasion (third case). 


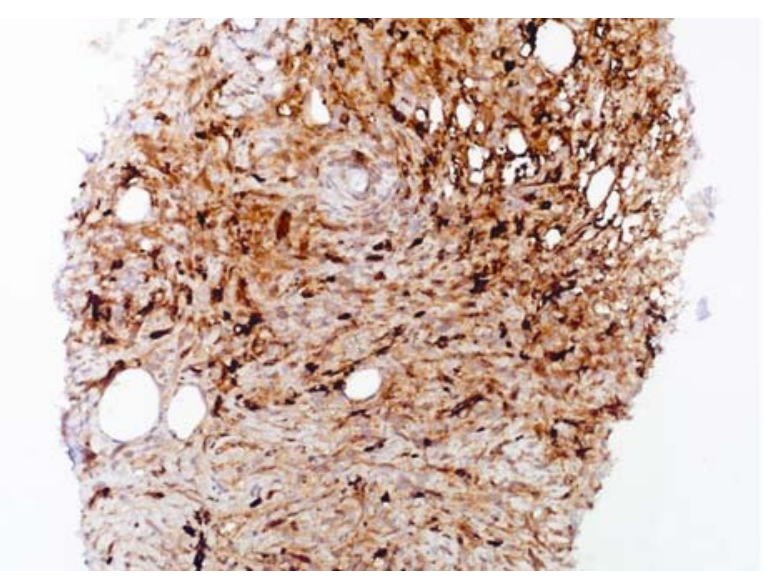

Figure 5. Immunhistochemically a high number of IgG4-positive plasma cells were seen (first case, brown color).

Steroid therapy was introduced (methylprednisolone given in dose of $1 \mathrm{mg}$ per $\mathrm{kg}$ of body weight). Due to the treatment patient's complaints disappeared, the elevated liver enzymes decreased to normal (see Table 1). Subsequent US, EUS and CT examination showed regression, as well (see Figure 6).

Table 1. Laboratory findings at the time of diagnosis (before therapy) and after three months of steroid therapy

\begin{tabular}{|c|c|c|c|c|c|c|}
\hline & \multicolumn{2}{|c|}{ First case: AIP } & \multicolumn{2}{|c|}{ Second case: AIP } & \multicolumn{2}{|l|}{ Third case: PC } \\
\hline & $\begin{array}{l}\text { Before } \\
\text { therapy }\end{array}$ & $\begin{array}{l}\text { In three } \\
\text { months' } \\
\text { time }\end{array}$ & Before therapy & $\begin{array}{l}\text { In three } \\
\text { months' } \\
\text { time }\end{array}$ & Before therapy & Normal value \\
\hline SGOT (U/1) & 643 & 13 & 238 & 18 & 13 & $5-38$ \\
\hline SGPT (U/l) & 394 & 32 & 277 & 50 & 11 & $5-39$ \\
\hline GGT (U/l) & 122 & 37 & 454 & 48 & 16 & $5-32$ \\
\hline Conj/Non conj & & & & & & \\
\hline Bilirubin $(\mu \mathrm{mol} / \mathrm{l})$ & $168 / 93$ & $53 / 11$ & $187.9 / 165.8$ & $8.9 /$ & $6.5 /$ & $4-20$ \\
\hline $\mathrm{AP}(\mathrm{U} / \mathrm{l})$ & 621 & 176 & 217 & 59 & 68 & $100-290$ \\
\hline LDH (U/1) & 624 & 336 & & & 323 & $200-400$ \\
\hline Amylase (U/l) & 15 & 16 & 23 & 63 & 44 & $0-220$ \\
\hline CRP (mg/l) & 1.64 & 0.47 & $<2.0$ & $<2.0$ & 3.9 & $0-5$ \\
\hline INR & 1.29 & 1.29 & 1.15 & 0.94 & 1.15 & $0.8-1.3$ \\
\hline $\begin{array}{l}\text { Blood glucose } \\
(\mathrm{mmol} / \mathrm{l})\end{array}$ & 5.9 & 15.4 & 9.5 & 8.8 & 6.2 & $3.5-5.8$ \\
\hline CA 19-9 (U/ml) & $<0.6$ & $<0.6$ & 26.61 & 20.78 & 7.85 & $<27.0$ \\
\hline CEA (ng/ml) & 7.94 & 3.11 & 1.41 & 2.36 & 5.18 & $<4.70$ \\
\hline
\end{tabular}

Note. $\mathrm{PC}=$ pancreas carcinoma; $\mathrm{SGOT}=$ serum glutamic oxaloacetic transaminase; $\mathrm{SGPT}=$ serum glutamic pyruvic transaminase; GGT = gamma-glutamyl transpeptidase; conj = conjugated; non conj = non conjugated; $\mathrm{LDH}=$ lactate dehydrogenase $\mathrm{CRP}=\mathrm{C}$ reactive protein; $\mathrm{INR}=$ international normalized ratio; $\mathrm{CA}$ 19-9 = carbohydrate/cancer antigen $19-9 ; \mathrm{CEA}=$ carcinoembryonic antigen. 


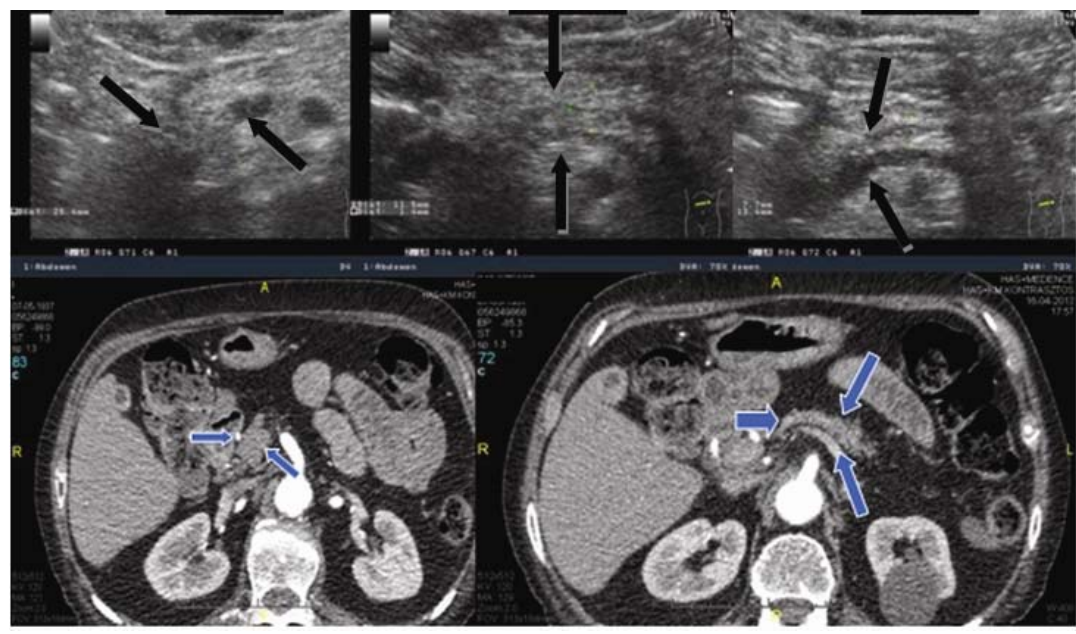

Figure 6. Abdominal US (top line) and CT (bottom line) made after steroid therapy: atrophic, diffuse slightly, inhomogenous pancreas (first case).

\subsection{Second case}

A 69-year old abstinent male was referred to the outpatient clinic because of painless jaundice. The laboratory tests showed slightly elevated obstructive liver enzymes (see Table 1). A suspicion of pancreatic cancer was emerged according to a mass-forming lesion in the head seen with US examination. The abdominal CT confirmed the abnormality revealed with the US. To ensure the bile flow the patient underwent an ERCP examination and during the procedure a double-duct sign was seen, which verified the diagnosis of malignancy. Biliary stenting was also performed. Radial EUS was carried out for staging, however there were not any nodular lesion detected during the examination, but a diffuse chronic pancreatitis, moreover no lymphadenomegaly had been seen. In addition, the tumor markers were not elevated (see Table 1). A core-biopsy was performed from the lesion seen on US and CT and the histological examination of the tissue sample established the diagnosis of AIP, which was confirmed with the extremely elevated serum IgG4-level (> $815 \mathrm{mg} / \mathrm{l})$, as well. To be on the safe side, an MRCP was made, which showed a diffuse enlargement of the pancreas, same as to the AIP. Due to steroid therapy the elevated liver enzymes decreased to normal and the patient's complaints disappeared. Three months later, after the steroid therapy, an ERCP was performed to remove the biliary stents while the examination revealed main pancreatic duct caliber change.

\subsection{Third case}

A 67-year old woman came to her GP because of epigastric pain. Preliminary laboratory tests did not reveal any pathologic (see Table 1). Pancreatic tumor was supposed due to a mass seen in the body of the pancreas with abdominal US. The same malignancy was suspected on abdominal CT scan beside an abdominal lymphadenomegaly. The patient was referred to our hospital for further investigation, i.e. EUS for staging and US-guided core-biopsy for histological examination, requested from her surgeon. The radial EUS clearly confirmed the tumor in the body, moreover the examination revealed both arterial and venous invasion of the malignant cells and lymphadenomegaly. On the other hand the core-biopsy did not show any malignancy moreover it was characteristic to AIP. What is more the tumor markers were in normal range. Nevertheless the patient underwent a surgical invention which showed a progressive, unresectable cancer on the greater omentum, as well, moreover the histological examination of the tissue sample taken during the surgery revealed adenocarcinoma of the pancreas.

\section{Discussion}

What common in all these three cases is that autoimmune pancreatitis, a quite rare disease, or the more frequent pancreatic cancer emerged as diagnosis. Tumor of the pancreas was suspected in all three cases according to the clinical 
manifestation and the conventional radiological examinations (e. g. abdominal US, abdominal CT). However malignancy only in one case (in the third one) was supported with radial EUS; moreover for that patient the core-biopsy revealed a false benign diagnosis (i.e. autoimmune pancreatitis). It is well known that in some cases samples can be taken from the "paratumoral" inflammatory region with the help of US-guided core-biopsy ${ }^{[11-14]}$ resulting in false negative diagnosis, however it is difficult to take this information into account in some certain cases.

In two of our cases the EUS was the only tool which revealed diffuse involvement of the pancreas giving a hand in making a diagnosis without surgical intervention, while in the third case it kept the diagnosis in the proper way by showing an infiltrative nodular disease.

The autoimmune pancreatitis is a special type of chronic pancreatitis, probably with autoimmune etiology, and displays clinical, histological and morphological features. Its incidence is not exactly known yet as it is probably not diagnosed in each case. (In Japan the prevalence is 0.8 case $/ 100000$ person and the $4 \%-10 \%$ of chronic pancreatitis is AIP ${ }^{[15,16]}$.)

In a study of the Mayo Clinic the pancreatic tissues taken out in Whipple-procedure because malignancy were re-examined retrospectively, which showed that in $9.2 \%$ of the cases there was no malignancy, and among these patients AIP was histologically diagnosed in $23.4 \%{ }^{[17]}$.

On the contrary the malignancies of the pancreas occur quite often ${ }^{[18]}$. In 2008 the pancreatic cancer worldwide was the 13 th most common cancer with 277,000 new cases (2.2\% among all type of the cancers) and the 8 th most common cause of death with 266,000 cases ( $3.5 \%$ among all type of death caused by cancer). The five-year survival is only $5 \%$.

The main clinical features of AIP and pancreatic cancer are nearly the same: jaundice, mild abdominal pain and weight-loss, while sometimes nausea, weakness and steatorrhoea occur also. According to the histological patterns two types of AIP exist. The histological pattern in type 1 AIP, referred to as lymphoplasmacytic sclerosing pancreatitis (LPSP), is characterized by a periductal lymphoplasmacytic infiltration, storiform fibrosis, obliterative phlebitis and IgG4-positive plasma cells. The histopathological pattern in type 2 AIP is known as idiopathic duct centric CP (IDCP) or granulocyte epithelial lesion (GEL)-positive pancreatitis. Periductal lymphoplasmacytic infiltration and storiform fibrosis can be seen in type 2 AIP, as well, while no or very few $(<10$ cells/high power field) IgG4-positive plasma cells occur in the tissue sample ${ }^{[19]}$. Immunological examinations in type 1 AIP patients have demonstrated high incidences of hypergammaglobulinemia (43\%), increased serum levels of immunoglobulin-G (IgG) (62\%-80\%) and $\operatorname{IgG} 4$ (68\%-92\%). Among all the serological diagnostic features, an elevated serum level of IgG4 has the highest individual diagnostic value; however, it is not disease-specific. Furthermore, an elevated serum IgG4 level correlates with the activity of AIP ${ }^{[20,21]}$.

In AIP we can find other organ involvement, like autoimmune thyroiditis, Sjögren's syndrome, interstitial nephritis, inflammatory bowel disease, primary biliary cirrhosis, and primary sclerosing cholangitis ${ }^{[15,22]}$.

Typically radiological examinations show a diffuse enlargement of the pancreas with a capsule-like rim, and the segmental stenosis of the main pancreatic duct (in contrary to chronic pancreatitis in which segmental duct dilation can be seen in the atrophic pancreas). Rarely can we see the focal enlargement of the pancreas which is hard to differentiate from a tumor. Several studies have shown that EUS is the most sensitive and most specific method of testing in the diagnosis of pancreatic tumors ${ }^{[23]}$. The EUS is especially conducive to the detection of small tumors, where other imaging modality (CT, magnetic resonance imaging) is not enough sensitive, but there is a chance of curative resection. Therefore EUS has an important role in differential diagnosis as being the most sensitive and specific diagnostic tool in pancreatic malignancies (with $98 \%$ sensitivity and $95 \%$ specificity), and it can exclude the pancreatic tumor reliably according to its $95 \%-100 \%$ negative predictive value ${ }^{[3,24]}$. The EUS is also suitable for assessing the pancreas parenchyma and the ducts thereby EUS is an important testing method in the diagnosis of chronic pancreatitis with high accuracy (sensitivity: 100\%, specificity: $79 \%)^{[25]}$. Isolation of EUS for the diagnosis of autoimmune pancreatitis and pancreatic carcinoma based on the typical morphology signs ${ }^{[26]}$. In addition the sensitivity (85\%) of the fine needle aspiration (FNA) with the help of EUS in 
the diagnosis of pancreas cancer, specificity (98\%), diagnostic accuracy (88\%), positive and negative predictive value $(100$ and $85 \%)$ is very high ${ }^{[27]}$. The EUS guided trucut biopsy proved to be more effective than the FNA in the diagnosis of autoimmune pancreatitis ${ }^{[28]}$.

In establishing the diagnosis of AIP the most common diagnostic criteria are the Mayo Clinic's one (HISORt criteria). While the latest diagnostic criteria of the International Association of Pancreatology is from 2011, and represent consensus of different guidelines ${ }^{[29]}$ (see Table 2).

Table 2. Diagnostic criteria for AIP: definitions

\begin{tabular}{|c|c|c|c|}
\hline & \multirow[t]{2}{*}{ The HISORt Criteria } & \multicolumn{2}{|c|}{$\begin{array}{l}\text { Guidelines of the International Association of } \\
\text { Pancreatology }\end{array}$} \\
\hline & & Type 1 & Type 2 \\
\hline Histology & typical histopathologic findings & $\begin{array}{l}\text { Lymphoplasmacytic } \\
\text { sclerosing pancreatitis }\end{array}$ & $\begin{array}{l}\text { Idiopathic duct-centric } \\
\text { pancreatitis or AIP with GEL }\end{array}$ \\
\hline Imaging & $\begin{array}{l}\text { Typical: diffusely enlarged gland with delayed } \\
\text { (rim) enhancement; diffusely irregular, } \\
\text { attenuated main pancreatic duct } \\
\text { Other: focal pancreatic mass/enlargement } \\
\text { mimicking pancreatic carcinoma }\end{array}$ & \multicolumn{2}{|c|}{$\begin{array}{l}\text { Typical: Diffuse enlargement with delayed enhancement } \\
\text { Indeterminate: Segmental/focal enlargement with delayed } \\
\text { enhancement }\end{array}$} \\
\hline Serology & elevated serum IgG4 level & $\begin{array}{l}\text { IgG4 } \geq 1 \mathrm{x} \text { upper limit of } \\
\text { normal value }\end{array}$ & - \\
\hline $\begin{array}{l}\text { Other organ } \\
\text { involvement }\end{array}$ & $\begin{array}{l}\text { autoimmune thyroiditis, Sjögren's syndrome, } \\
\text { interstitial nephritis, inflammatory bowel } \\
\text { disease, primary biliary cirrhosis, primary } \\
\text { sclerosing cholangitis }\end{array}$ & $\begin{array}{l}\text { Typical AIP-like } \\
\text { histology of } \\
\text { extrapancreatic organs } \\
\text { Or: Segmental/multiple } \\
\text { proximal (hilar/ } \\
\text { intrahepatic) or proximal } \\
\text { and distal bile duct } \\
\text { stricture } \\
\text { And/Or: Retroperitoneal } \\
\text { fibrosis }\end{array}$ & $\begin{array}{l}\text { No or clinically diagnosed } \\
\text { inflammatory bowel } \\
\text { disease }\end{array}$ \\
\hline $\begin{array}{l}\text { Response to } \\
\text { steroid } \\
\text { therapy }\end{array}$ & $\begin{array}{l}\text { resolution/marked improvement of } \\
\text { pancreatic/extrapancreatic manifestation with } \\
\text { steroid therapy }\end{array}$ & $\begin{array}{l}\text { Diagnostic steroid trial } \\
\text { Rapid }(\leq 2 \mathrm{wk}) \text { radiologic } \\
\text { marked improvement in } \mathrm{p} \\
\text { manifestations }\end{array}$ & $\begin{array}{l}\text { y demonstrable resolution or } \\
\text { creatic/ extrapancreatic }\end{array}$ \\
\hline
\end{tabular}

Note. $\mathrm{AIP}=$ autoimmune pancreatitis; $\mathrm{GEL}$ = granulocyte epithelial lesion; $\mathrm{IgG} 4=$ immunglobulin $\mathrm{G} 4$.

The short term prognosis of AIP is very good, due to the rapid improvement seen in the patient's condition through steroid therapy (however if we cannot see the improvement, the diagnosis has to be reconsider) ${ }^{[15,30,31]}$. The long term prognosis has not been discovered yet.

\section{Conclusion}

The correct diagnosis has to be established multidisciplinary (radiology, endoscopy, laboratory diagnostics, and other related specialties) to diminish the occurrence of misdiagnosis, however it cannot be entirely excluded. This statement is really true in relation to the pancreatic tumors as it can be seen in our cases, as well. However, the radiological tools 
usually used in the practice are overvalued, their sensitivity is not sufficient enough. According to these facts, it is important to have EUS become part of everyday use; moreover its sensitivity is much higher than the widely used CT's but in Hungary it is a rather underestimated method. The diagnostic EUS is useful not only in case of uncertainty of the easily available conventional radiological tools, but to clarify their description (e.g. staging) as well, both in malignancies and inflammatory diseases ${ }^{[20]}$.

Additionally from our cases it is well seen that EUS, besides the more precise diagnosis, might be a cost-cutting method, because both the patient and the medical institution can be avoided from some unnecessary and expensive surgical interventions.

\section{References}

[1] Zhang DX, Dai YD, Yuan SX, Tao L. Prognostic factors in patients with pancreatic cancer. Exp Ther Med. 2012 Mar; 3(3): 423-32.

[2] Fusaroli, P, Kypraios D, Caletti G, Eloubeidi MA. Pancreatico-biliary endoscopic ultrasound: A systematic review of the levels of evidence, performance and outcomes. World J Gastroenterol. 2012 Aug; 18(32): 4243-56. http://dx.doi.org/ 10.3748/wjg.v18.i32.4243

[3] Tellez-Avila FI, Chavez-Tapia NC, López-Arce G Franco-Guzmán AM, Sosa-Lozano LA, Alfaro-Lara R, Chan-Nuñez C, et al. Vascular invasion in pancreatic cancer: predictive values for endoscopic ultrasound and computed tomography imaging. Pancreas. 2012 May; 41(4):636-8. http://dx.doi.org/ 10.1097/MPA.0b013e31823e3632.

[4] Walsh TN, Rode J, Theis BA, Russel RC. Minimal change chronic pancreatitis. Gut 1992 Nov; 33(11): $1566-71$.

[5] Bhutani MJ, Arantes VN, Verma D Moezzi J, Suryaprasad S, Kapadia AS, Gopalswamy N. Histopathologic correlation of endoscopic ultrasound findings of chronic pancreatitis in human autopsies. Pancreas 2009 Oct; 38(7): 820-4. . http://dx.doi.org/10.1097/MPA.0b013e3181b2bc1a

[6] Wiersema MJ, Hawes RH, Lehman GA Kochman ML, Sherman S, Kopecky KK. Prospective evaluation of endoscopic ultrasonography and endoscopic retrograde cholangiopancreatography in patients with chronic abdominal pain of suspected pancreatic origin. Endoscopy 1993 Nov; 25(9): 555-64.

[7] Kahl S, Glasbrenner B, Leodolter A, Pross M, Schulz HU, Malfertheiner P. EUS in the diagnosis of early chronic pancreatitis: a prospective follow-up study. Gastrointest Endosc. 2002 Apr; 55(4): 507-11.

[8] Jones SN, Lees WR, Frost RA. Diagnosis and grading of chronic pancreatitis by morphological criteriaderived by ultrasound and pancreatography. Clin Radiol. 1988 Jan; 39(1): 43-8.

[9] Lees WR. Endoscopic ultrasonography of chronic pancreatitis and pancreatic pseudocysts. Scand J Gastroenterol Suppl. 1986; 123:123-9.

[10] Andersson R, Vagianos CE, Williamson RC. Preoperative staging and evaluation of resectability in pancreatic ductal adenocarcinoma HPB (Oxford). 2004; 6(1): 5-12. http://dx.doi.org/ 10.1080/13651820310017093

[11] Zech CJ, Helmberger T, Wichmann MW, Holzknecht N, Diebold J, Reiser MF. Large core biopsy of the pancreas under CT fluoroscopy control: results and complications. J Comput Assist Tomogr. 2002 Sep-Oct; 26(5): 743 -9.

[12] Elvin A, Andersson T, Scheibenpflug L, Lindgren PG. Biopsy of the pancreas with a biopsy gun. Radiology. 1990 Sep; $176(3)$ : 677 -9 .

[13] Jennings PE, Donald JJ, Coral A, Rode J, Lees WR. Ultrasound-guided core biopsy. Lancet. 1989 Jun; 1(8651): $1369-71$.

[14] Karlson BM, Forsman CA, Wilander E, Skogseid B, Lindgren PG, Jacobson G, Rastad J. Efficiency of percutaneous core biopsy in pancreatic tumor diagnosis. Surgery 1996 Jul; 120(1): 75-9.

[15] Detlefsen S, Drewes A: Autoimmun pancreatitis. Skand J Gastroenterol. 2009; 44(12): 1391-1407. http://dx.doi.org/ 10.3109/00365520903358881

[16] Czakó L, Gyökeres T, Topa L, Sahin P, Takács T, Vincze A, Dubravcsik Z, Szepes A, Pap A, Földesi I, Terzin V, Tiszlavicz L, Wittmann T. Autoimmun pancreatitis in Hungary: A multicenter nationwide study. Pancreatology 2011; 11(2): 261-7. http://dx.doi.org/ 10.1159/000327092

[17] Abraham SC, Wilentz R, Yeo C. Sohn TA, Cameron JL, Boitnott JK, Hruban RH. Pancreaticoduodenectomy (Whipple resections) in patients without malignancy. Am J Surg Pathol. 2003 Jan; 27(1): 110-20.

[18] Ferlay J, Shin HR, Bray F, Forman D, Mathers C, Parkin DM. Estimates of worldwide burden of cancer in 2008: GLOBOCAN 2008. Int J Cancer. 2010 Dec; 127(12): 2893-17. http://dx.doi.org/ 10.1002/ijc.25516. 
[19] Detlefsen S, Löhr JM, Drewes AM, Frøkjær JB, Klöppel G. Current concepts in the diagnosis and treatment of type 1 and type 2 autoimmune pancreatitis. Recent Pat Inflamm Allergy Drug Discov. 2011 May; 5(2): 136-49.

[20] Hamano H, Kawa S, Horiuchi A, Unno H, Furuya N, Akamatsu T, Fukushima M, Nikaido T, Nakayama K, Usuda N, Kiyosawa K. High serum IgG4 concentrations in patients with sclerosing pancreatitis. N Engl J Med. 2001 Mar; 344(10): 732-8.

[21] Choi EK, Kim MH, Lee TY, Kwon S, Oh HC, Hwang CY, Seo DW, Lee SS, Lee SK. The sensitivity and specificity of serum immunoglobulin $\mathrm{G}$ and immunoglobulin G4 levels in the diagnosis of autoimmune chronic pancreatitis: Korean experience. Pancreas. 2007 Aug; 35(2): 156-61.

[22] Czakó L. Autoimmun pancreatitis. Alul diagnosztizált kórkép?/Autoimmune pancreatitis - an underdiagnosed disease? LAM. 2006; 16(6): 505-10.

[23] Michl P, Pauls S, Gress TM. Evidence-based diagnosis and staging of pancreatic cancer. Best Pract Res Clin Gastroenterol. 2006 Apr; 20(2): 227-51.

[24] Czakó L, Szepes Z, Szepes A. Diagnosztikus endoszkópos ultrahang alkalmazása a tápcsatornában./Diagnostic endoscopic ultrasonography in the gastrointestinal tract. Orv Hetil. 2012 Jan; 153(3): 93-101. http://dx.doi.org/10.1556/OH.2012.29288

[25] Catalano, MF, Sahai A, Levy M, Romagnuolo J, Wiersema M, Brugge W, et al. EUS-based criteria for the diagnosis of chronic pancreatitis: the Rosemont classification. Gastrointest Endosc. 2009 Jun; 69(7): 1251-61. http://dx.doi.org/10.1016/j.gie.2008.07.043.

[26] Hoki, N, Mizuno N, Sawaki A, Tajika M, Takayama R, Shimizu Y, et al. Diagnosis of autoimmune pancreatitis using endoscopic ultrasonography. J Gastroenterol. 2009; 44 (2): 154-9. http://dx.doi.org/10.1007/s00535-008-2294-2.

[27] Mizuno N, Hara K, Hijioka S, Bhatia V, Shimizu Y, Yatabe Y, Yamao K. Current concept of endoscopic ultrasound-guided fine needle aspiration for pancreatic cancer. Pancreatology. 2011, 11 Suppl 2: 40-6. http://dx.doi.org/10.1159/000323502.

[28] Mizuno N, Bhatia V, Hosoda W, Sawaki A, Hoki N, Hara K, et al. Histological diagnosis of autoimmune pancreatitis using EUH-guided trucut biopsy: a comparison study with EUH-FNA. J Gastroenterol. 2009; 44(7): 742-50. http://dx.doi.org/10.1007/s00535-009-0062-6.

[29] Shimosegawa T, Chari S, Frulloni L, Kamisawa T, Kawa S, Mino-Kenudson M, Kim MH, Klöppel G, Lerch MM, Löhr M, Notohara K, Okazaki K, Schneider A, Zhang L; International Association of Pancreatology. International consensus diagnostic criteria for autoimmune pancreatitis: guidelines of the International Association of Pancreatology. Pancreas. 2011 Apr; 40(3): 352-8. http://dx.doi.org/ 10.1097/MPA.0b013e3182142fd2

[30] Song MH, Kim MH, Lee SK Seo DW, Lee SS, Han J, Kim KP, et al. Regression of pancreatic fibrosis after steroid therapy in patients with autoimmune chronic pancreatitis. Pancreas. 2005 Jan; 30(1): 83-6.

[31] Kamisawa T, Okazaki K., Kawa S, Shimosegawa T, Tanaka M; Research Committee for Intractable Pancreatic Disease and Japan Pancreas Society. Japanese consensus guidelines for management of autoimmune pancreatitis: III. Treatment and prognosis of AIP. J Gastroenterol. 2010 May; 45(5): 471-7. http://dx.doi.org/ 10.1007/s00535-010-0221-9 